\title{
Assessment of innovation risks in the context of sustainable development
}

\author{
Dilyara Zaynullina*1[0000-0002-2835-2935] \\ ${ }^{1}$ Kazan State University of Architecture and Engineering, 420043 Kazan, Russia
}

\begin{abstract}
It is obvious that any innovative activity is associated with risk, but the functioning of Russian innovative companies is the subject to even greater uncertainty. It is due to the lack of government support, the difficulty of forecasting the Russian economy, the influence of external factors, etc. Uncertainty in the context of sustainable development is a source of risk, and it should be reduced by obtaining information, at best, trying to lower uncertainty to zero by obtaining reliable and accurate information. The purpose of this study is a qualitative assessment of the innovative project's risks of various types of activities implemented in the Republic of Tatarstan. The author conducted an expert survey in the field of innovative economics: representatives of business and science. The expert survey covered the following main areas: qualitative risk assessment of a group of innovative projects and the potential impact of risks on the formation of management strategies that integrate risk management methods that companies plan to use. According to the results of the analysis of the expert survey, it is clear that for innovative projects in the service sector, the most dangerous are marketing, organizational, credit and technical risks. The technical risk is the most critical for innovative projects in the manufacturing industry, as well as the marketing, natural and climatic risk and the risk of lost. As for the extractive industry, technical and natural-climatic risks have the highest probability of occurrence. Keywords. Innovative projects, innovative risks, qualitative risk analysis, types of economic activities.
\end{abstract}

\section{Introduction}

The formation of a sustainable economy is associated with innovation process, which in turn is related to risks caused by uncertainty of results, variability of goals, etc.

Firstly, it is even more dangerous to invest in Russian innovative projects, since there is practically no tax relief for innovative companies in the national innovation system. Secondly, the risks of investing in innovation are also related to the fact that the successful completion of the innovation process in Russian conditions is almost impossible to guarantee. Thirdly, Russian innovative companies have to operate in conditions of increased uncertainty of internal and external factors $[1,2]$.

\footnotetext{
*Corresponding author: yadilyara@gmail.com
} 
In the context of sustainable development, the essence of uncertainty is based on the impact of various factors, such as:

- time uncertainty is due to the fact that it is impossible to predict for sure the occurrence of any factor in the future [3];

- uncertainty of market conditions [4];

- impossibility to predict the behavior of participants in a conflict of interest, etc [5].

The combination of all these factors in practice creates a large spectrum of different types of uncertainty. The uncertainty is a source of risk, that is why it should be reduced by obtaining information, at best, trying to reduce uncertainty to zero by obtaining reliable, highquality, accurate information [6].

The article «The influence of resistance to change on evaluating an innovation project's innovativeness and risk: A sensemaking perspective» shows that an individual's resistance to change moderates the positive relationship between project innovativeness and its perceived risk. The strength and direction of this moderation effect depends on the underlying interpretation of an organization's context. An opportunity is associated with negative moderation that reduces perceivable risks, while the context of a threat is associated with a positive moderation that reinforces the perception of risks [7].

The authors of the article «Risk management in small hydropower (SHP) projects of Uttarakhand: An innovative approach: Risk management in small hydropower projects» think that despite the huge investment potential in the small hydropower (SHP) sector, investors are not very enthusiastic about investing in the sector owing to the uncertainty associated with project costs. The paper supports investors in making better investment decisions, helps insurance companies arrive at variable insurance premium policies and assists policymakers by identifying sensitive pain points [8].

In the study «Service innovation management in a modern economy: Insights on the interplay between firms' innovative culture and project-level success factors» data drawn from a sample of 502 hotels and knowledge-intensive business service firms located in Spain allows testing the relationships among organizational and project-level success factors in new service development. Empirical evidence reveals several routes of effects useful to trigger external new service performance or market success, and internal new service performance, or the satisfaction, motivation, and commitment of front-line employees [9].

In this way, the author aims to a qualitative assessment of the innovative projects risks of various types of activities implemented in the Republic of Tatarstan, as well as the identification of the most significant types of risks by project groups [10].

\section{Materials and methods}

\subsection{Materials}

The Republic of Tatarstan, being one of the most dynamic and industrially developed Russian regions, successfully implements the sustainable development goals at the regional level. Therefore, the author chose about 200 innovative projects, various types of economic activities implemented in the republic [11].

The distribution of the studied sample of innovative projects by the type of economy activity is presented in Table 1 .

The study of risks of innovative projects in industry and service sector is based on the results of an expert survey. It was attended by 128 specialists from among the managers and employees of innovative companies (62\%), teachers of Kazan (Volga Region) Federal University (KFU) (17\%) and Kazan State University of Architecture and Engineering (KSUAE) (21\%). 
Table 1. Distribution of the studied sample of innovative projects by the type of economic activity.

\begin{tabular}{|c|c|c|c|c|}
\hline № & Industry & Innovative projects & Quantity & $\begin{array}{l}\text { Specific } \\
\text { weight }\end{array}$ \\
\hline \multicolumn{5}{|c|}{ Industry } \\
\hline 1 & Agriculture & $\begin{array}{l}\text { 1. Energy source for recycling of } \\
\text { agricultural waste }\end{array}$ & 1 & $4.35 \%$ \\
\hline 2 & Petrochemicals & $\begin{array}{l}\text { 1. Processing of natural bitumen, high- } \\
\text { viscosity oil fuel oil and tar; } \\
\text { 2. Bituminous polymer binders with } \\
\text { extended operating temperature range; } \\
\text { 3. Creation of a new material of } \\
\text { polyethylene-plastic, which reduces the } \\
\text { weight of the product by } 10 \text { times; }\end{array}$ & 3 & $13 \%$ \\
\hline 3 & Nanotechnology & $\begin{array}{l}\text { Lithium-ion battery with negative } \\
\text { electrode made of nanocomposite material; } \\
\text { 2. Nanopowders of metals, their compounds } \\
\text { and alloys of high purity; }\end{array}$ & 2 & $8.7 \%$ \\
\hline 4 & Food industry & $\begin{array}{l}\text { 1. Technology of purification of sugar- } \\
\text { containing syrups and solutions }\end{array}$ & 1 & $4.35 \%$ \\
\hline 5 & $\begin{array}{l}\text { Processing } \\
\text { industry }\end{array}$ & $\begin{array}{l}\text { 1. Test system for assessing the risk of } \\
\text { waste, substances, materials } \\
\text { 2. Processing of automotive catalysts and } \\
\text { extraction of platinum group metals from } \\
\text { them }\end{array}$ & 2 & $8.7 \%$ \\
\hline 6 & Oil industry & $\begin{array}{l}\text { 1. Energy-saving method of soft, non- } \\
\text { destructive impact on the well }\end{array}$ & 1 & $4.35 \%$ \\
\hline 7 & $\begin{array}{l}\text { Innovative } \\
\text { technologies in } \\
\text { medicine }\end{array}$ & $\begin{array}{l}\text { 1. Biogel for gluing various tissues of a } \\
\text { living organism; } \\
\text { 2. Capsule for non-invasive bile sampling: } \\
\text { 3. Autovaccine for cancer treatment; } \\
\text { 4. System for targeted delivery of medicinal } \\
\text { substances; } \\
\text { 5. Computer test simulator for determining } \\
\text { the psychological mood (state) }\end{array}$ & 5 & $21.7 \%$ \\
\hline \multicolumn{5}{|c|}{ Service sector } \\
\hline 8 & $\begin{array}{l}\text { Automation of } \\
\text { management } \\
\text { systems }\end{array}$ & $\begin{array}{l}\text { 1. Automation of the restaurant business; } \\
\text { 2. Task execution monitoring and control } \\
\text { system; } \\
\text { 3. A service that helps you choose } \\
\text { convenient travel companions; } \\
\text { 4. Development of a control method for } \\
\text { remote fire extinguishing; }\end{array}$ & 4 & $17.45 \%$ \\
\hline 9 & Education & $\begin{array}{l}\text { 1. Electron-optical systems, educational and } \\
\text { laboratory complexes }\end{array}$ & 1 & $4.35 \%$ \\
\hline 10 & Trade sphere & $\begin{array}{l}\text { 1. Universal service for registering } \\
\text { purchases made in real trade on the Internet }\end{array}$ & 1 & $4.35 \%$ \\
\hline 11 & $\begin{array}{c}\text { Construction and } \\
\text { housing }\end{array}$ & $\begin{array}{l}\text { 1. Internet service that allows to manage } \\
\text { housing and non-housing stock }\end{array}$ & 1 & $4.35 \%$ \\
\hline 12 & $\begin{array}{c}\text { Information } \\
\text { technology (IT) }\end{array}$ & $\begin{array}{l}\text { 1. The device «Infon», which provides a } \\
\text { connection via the Internet and telephone }\end{array}$ & 1 & $4.35 \%$ \\
\hline
\end{tabular}

Note. Calculated by the author.

The expert survey covered the following directions: qualitative and quantitative risk assessment of a group of innovative projects and the potential impact of risks on the 
management strategies formation in context of sustainable development that integrate risk management methods that companies plan to use.

The main factors of uncertainty of external environment and, therefore, sources of risk in the context of sustainable development are:

- the unpredictability of unfavorable natural processes and fact;

- the randomness, as the multivariance manifestation of various socio-economic and technological processes [12];

- the manifestation of opposite trends in the form of a struggle of contradictions in various areas of socio-economic, political, technological and other spheres of activity, including business and innovation [13];

- the poor predictability of the innovative projects results, because the expected results of an innovative project can be predicted only at short time intervals [14];

- the incompleteness and inaccuracy of information about the project and the processes in the internal and external environment of the project [15];

- the limited availability of the necessary material, financial and human resources while making management decision [16];

- the limitations of innovation activity due to differences in motivation, attitudes, goals, and behavioral patterns of employees of the company [17].

\subsection{Methods}

Risk assessment is the most important part in risk management and it has quantitative and qualitative method for calculation the amount of risk. The result of qualitative methods is verbal (descriptive) or expert models of project risks. This method is used for a preliminary assessment of project risk, before developing a business plan. The paper is devoted to qualitative risk assessment [18].

The existing four-level classification system allows identifying the composition of simple or primary risks. Those ones that are not subject to further division. These risks include:

- natural and climatic risks;

- production, technical and technological risks;

- criminal and legal risks;

- country risks;

- tax risks;

- marketing risks;

- organizational risks;

- inflationary risks;

- deflationary risks;

- interest rate risks;

- risks of lost profits;

- translational currency risks;

- credit risks related to the borrower;

- credit risks regarding the method of securing the debt [19-20].

\section{Results and discussion}

To assess the risks of certain types of innovative projects, the participants of the expert survey were asked to add other less general types of risk to the classification presented above. Those risks reflect the specifics of the area in which the innovation project is supposed to be implemented. Figures 1 to 3 below show the values of all risks identified by experts as possible for one innovation project from each group by type of economic activity. 


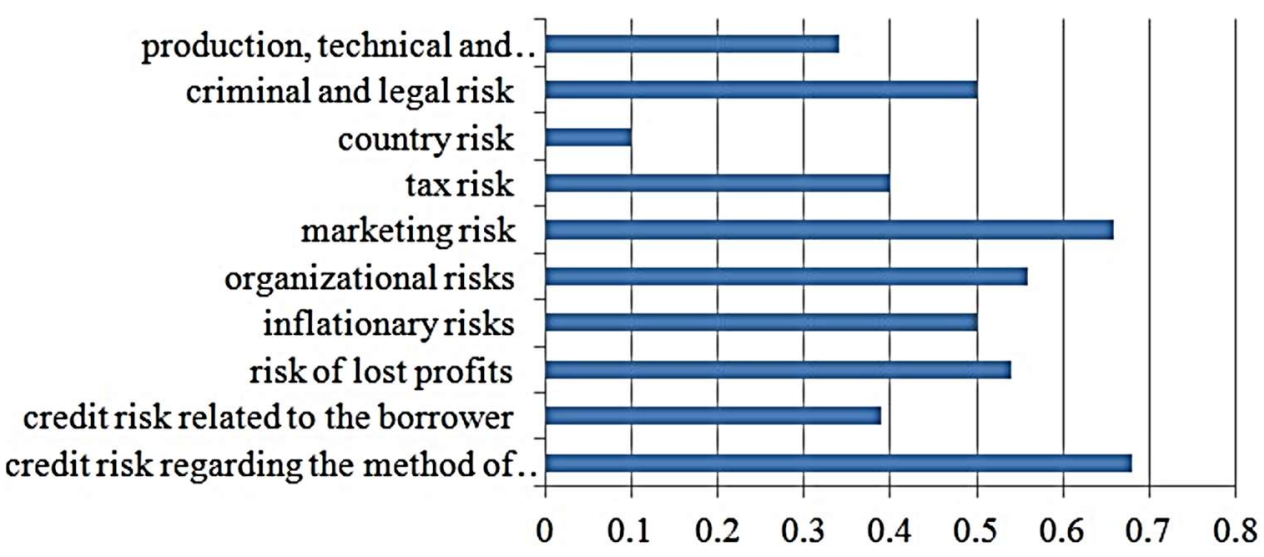

Fig. 1. Values of risks arising in the implementation of an innovative project in the service sector.

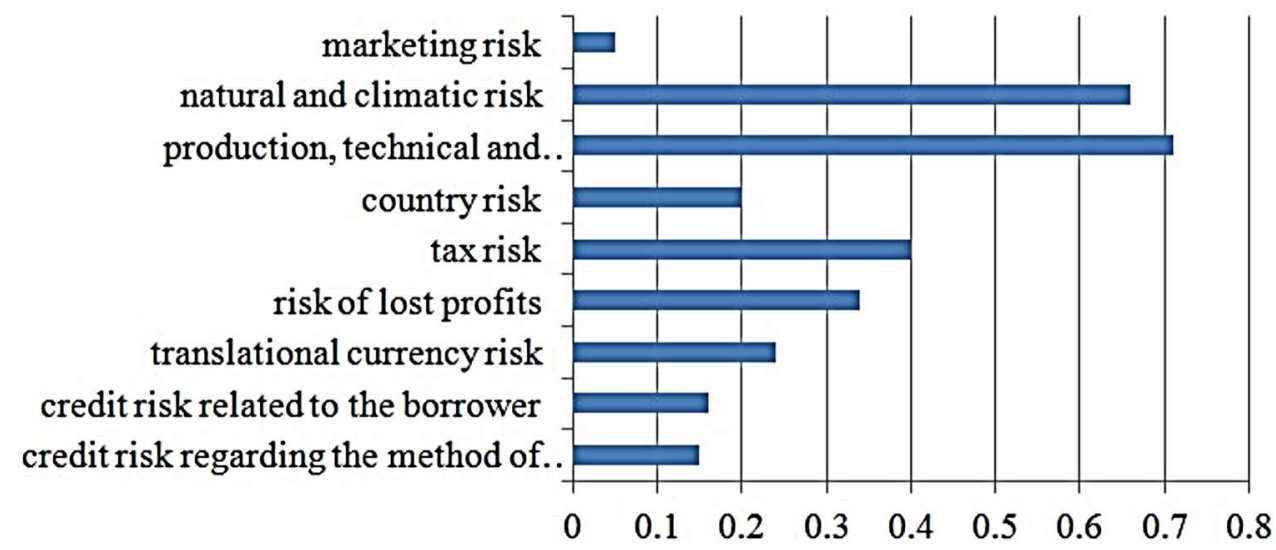

Fig. 2. Values of risks arising in the implementation of an innovative project in the manufacturing industry.

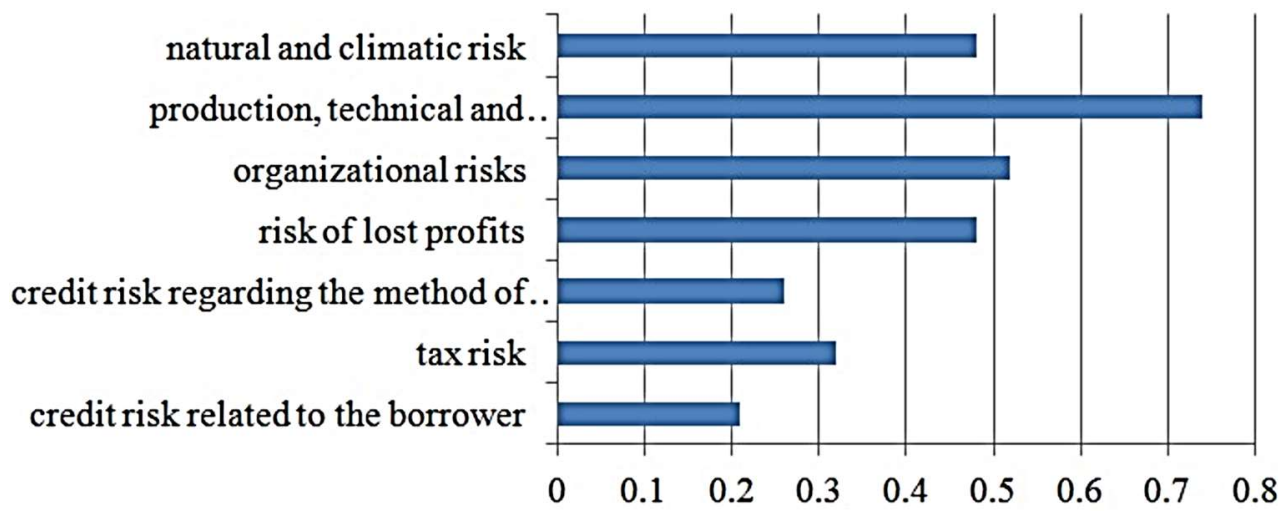

Fig. 3. Values of risks arising in the implementation of an innovative project of the extractive industry.

Quantitative assessment of innovative risks will increase the validity and quality of management decisions that contribute to the successful implementation of an innovative project.

There are five areas in quantifying risks that characterize the company's gain (profit) or its losses: the risk-free area, the area of minimal risk, the area of increased risk, the area of critical risk and the area of unacceptable risk (Table 2). 
Table 2. Areas highlighted in the risk assessment.

\begin{tabular}{|c|c|c|c|c|}
\hline Gain & \multicolumn{4}{|c|}{ Loss } \\
\hline \multicolumn{5}{|c|}{ Areas } \\
\hline Risk-free & Minimum Risk & Increased risk & Critical risk & Unacceptable risk \\
\hline
\end{tabular}

Within the critical risk area, losses are likely to exceed the estimated profit, but do not exceed the gross profit. The risk value in this area ranges from 0.5-0.75. This risk is undesirable, as the company is in danger of losing all its revenue from this activity.

Within the area of unacceptable risk, losses are likely to be commensurate with the amount of own funds, the onset of complete bankruptcy of the enterprise. In this area, the risk factor is in the range of $0.75-1$.

\section{Conclusions}

An analysis of an expert survey on innovation risks led to the following conclusions.

The most dangerous risks for innovative projects in the service sector are marketing, organizational, credit and production and technical. These types of risks were noted by experts as likely in $50 \%$ of the projects.

The most dangerous risks for projects in the manufacturing industry are the production risk; it occurs in $100 \%$ of the projects cases with a probability of 0.54 to 0.75 , as well as the marketing, natural and climatic risk and the risk of lost profits in half of the cases.

As for the extractive industry, the most dangerous risks with a high probability of occurrence of a negative event are production and technological and natural-climatic risks. They occur in $100 \%$ of the projects with a probability of occurrence of a negative event of 0.75 and 0.65 , respectively.

Considering that innovation management is the starting point in of the sustainable economy formation, and innovative projects have the highest risks for investment, initiators and investors of such projects need to accurately assess their capabilities. The conducted expert survey will allow carrying out a qualitative risk assessment of groups of innovative projects of various types of economic activity in the future.

\section{References}

1. J. Wang, W. Lin, Y.H. Huang. A performance-oriented risk management framework for innovative $R \& D$ projects, Technovation 30, 601-611 (2010). DOI: 10.1016/j. technovation.2010.07.003.

2. G. Du, Z. Liu, H. Lu. Application of innovative risk early warning mode under big data technology in Internet credit financial risk assessment, J. Comput. Appl. Math. 386, 113260 (2021). DOI: 10.1016/j.cam.2020.113260.

3. C. Berloco, G. De Francisci Morales, D. Frassineti, G. Greco, H. Kumarasinghe, M. Lamieri, E. Massaro, A. Miola, S. Yang. Predicting corporate credit risk: Network contagion via trade credit, PLoS One 16, e0250115 (2021). DOI: 10.1371/journal.pone. 0250115.

4. M. Pirozzi, L. Di Donato, L. Tomassini, A. Ferraro. Possible innovative technical measures for risk prevention during the use of mobile machines with remote guide/control, Procedia Manufacturing, 457-461 (2020). DOI: 10.1016/j.promfg. 2020.02.049.

5. A. Brattström, J. Frishammar, A. Richtnér, D. Pflueger. Can innovation be measured? A 
framework of how measurement of innovation engages attention in firms, J. Eng. Technol. Manag. 48, 64-75 (2018). DOI: 10.1016/j.jengtecman.2018.04.003.

6. M.J. Trotter, P.M. Salmon, M.G. Lenné. Impromaps: Applying Rasmussen's Risk Management Framework to improvisation incidents, Saf. Sci. 64, 60-70 (2014). DOI: 10.1016/j.ssci.2013.11.021.

7. T. Röth, P. Spieth. The influence of resistance to change on evaluating an innovation project's innovativeness and risk: A sensemaking perspective, J. Bus. Res. 101, 83-92 (2019). DOI: 10.1016/j.jbusres.2019.04.014.

8. N.C. Roy. Risk management in small hydropower (SHP) projects of Uttarakhand: An innovative approach: Risk management in small hydropower projects, IIMB Manag. Rev. 32, 291-304 (2020). DOI: 10.1016/j.iimb.2019.10.012.

9. M.L. Santos-Vijande, J.Á. López-Sánchez, P. Pascual-Fernández, J.M. Rudd. Service innovation management in a modern economy: Insights on the interplay between firms' innovative culture and project-level success factors, Technol. Forecast. Soc. Change 165, 120562 (2021). DOI: 10.1016/j.techfore.2020.120562.

10. A. Boobis, M. Embry, T. Pastoor. The HESI Risk 21 project: An innovative tool in risk assessment, Toxicol. Lett. 280, S56 (2017). DOI: 10.1016/j.toxlet.2017.07.139.

11. A. Romanova, I. Evgeniya. Operational services management in the context of sustainable development of intelligent technologies, IOP Conf. Ser. Mater. Sci. Eng. 890, (2020). DOI: 10.1088/1757-899X/890/1/012183.

12. A. Gurtuev, E. Derkach, S. Makhosheva, Z. Ivanov. A Bayesian approach to investment in innovation projects with the presence of fake innovators, Heliyon 6, e05603 (2020). DOI: 10.1016/j.heliyon.2020.e05603.

13. O. Kleshcheva, F. Sayfullina, N. Abdukhanova. Complex criterion for evaluating contractor's activities in the construction industry, IOP Conf. Ser. Mater. Sci. Eng. 890, (2020). DOI: 10.1088/1757-899X/890/1/012116.

14. E. Shagiakhmetova, O. Borovskikh, A. Nizamova, T. Kazymova. Multivariate model of construction project operational efficiency, IOP Conf. Ser. Mater. Sci. Eng. 890, (2020). DOI: 10.1088/1757-899X/890/1/012113.

15. 15. Ustinova, L., Sirazetdinov, R.: Factors affecting the parameters of the construction industry. IOP Conf. Ser. Mater. Sci. Eng. 890, (2020). https://doi.org/10.1088/1757899X/890/1/012117.

16. O. Bakhareva, T. Azhimov, L. Azhimova, L. Marfina, A. Khuzagaripov. The classification of transaction costs: The innovation in the construction industry based on building information modeling. A case study of multilingual schools, IOP Conf. Ser. Mater. Sci. Eng. 890, (2020). DOI: 10.1088/1757-899X/890/1/012118.

17. A. Afanasyeva, R. Safma, I. Kursina. Sustainable cities: Major challenges and trends, IOP Conf. Ser. Mater. Sci. Eng. 890, (2020). DOI: 10.1088/1757-899X/890/1/012181.

18. Sychev, M., Evstafieva, A., Pozdeev, V., Chugunova, I.: Management of sustainable economic potential of construction enterprise. IOP Conf. Ser. Mater. Sci. Eng. 890, (2020). DOI: 10.1088/1757-899X/890/1/012115.

19. E. Shagiakhmetova, Y. Medyanik, L. Gimadieva, D. Vakhitova, I. Yarullina. Economic efficiency of plastic recycling plant construction, IOP Conf. Ser. Mater. Sci. Eng. 890, (2020). DOI: 10.1088/1757-899X/890/1/012114.

20. H. Lionboui, T. Benabdelouahab, A. Htitiou, Y. Lebrini, A. Boudhar, R. Hadria, F. Elame. Spatial assessment of losses in wheat production value: A need for an innovative approach to guide risk management policies, Remote Sens. Appl. Soc. Environ 18, 100300 (2020). DOI: 10.1016/j.rsase.2020.100300. 